\title{
THE EARLY SLAVIC SUNKEN HOUSE FROM SENICA
}

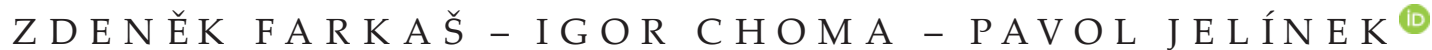

\begin{abstract}
A rescue archaeological research in Senica, part Párovce was performed in a polyculture settlement and a part of a skeletal burial ground attributed to the Únětice culture from the Early Bronze Age. The present paper discusses finds from the early Slavic period. A sunken house with remains of a stone-soil furnace and an oval pit belongs to the settlement phase. Based on the Prague-type pottery, the features are both dated back to the $6^{\text {th }} \mathrm{c}$. The settlement, thus, could be considered to be the oldest evidence of the Slavic presence in western Záhorie, in the Myjava and Teplica basins.
\end{abstract}

Keywords: Western Slovakia, Prague culture, Early Slavic Period, sunken house.

Between 2015 and 2017, the Slovak National Museum, Archaeological Museum in Bratislava performed rescue archaeological researches in Senica, part Párovce (Senica distr.). The excavations were motivated by the construction of accommodation and restaurant facilities and revealed a polyculture settlement site ranging from the Neolithic period to the High Middle Ages and a skeletal burial ground from the Early Bronze Age. Párovce hills are located in the south-eastern part of the Chvojnice Uplands, on a tip of a Pleistocene

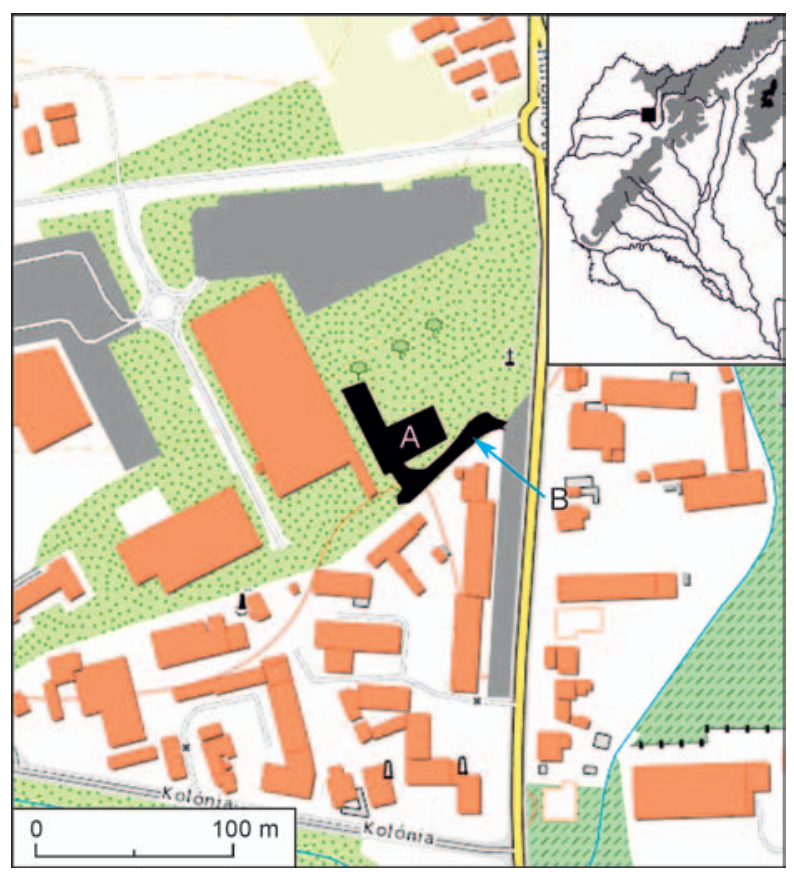

Fig. 1. Senica, part Párovce. A - site revealed during the archaeological research; B - location of feature no. 32, a sunken house from the early Slavic period. Background map: ZBGIS. terrace forming a loess promontory over the confluence of the Rovenský creek and the Teplica river (Fig. 1). The archaeological site is located about $205 \mathrm{~m}$ a.s.l., about $4-5 \mathrm{~m}$ above the neighbouring river valleys. The promontory, thus, offers a wide view over the area, up to the Little Carpathians, towards the Zámčisko massive or the Myjava Upland. Geologically, the upland consists of the Quaternary sediments dated back to the Middle Pleistocene, fluvial sediments covered with loess, diluvial clays and flushings with modal and cultural brown earth on the top of it. Archaeological research, often limited to surface surveys, started there at the turn of first and second decades of the current century due to the construction of commercial facilities (Daňo 2011, 81; Hoššo/Piatničkovál Šuteková 2011; Vávra/Bača 2016, 55 ff., 119).

The site that aroused the interest of the Slovak National Museum, Archaeological Museum in Bratislava was located to the east of the site where a Kaufland supermarket had been planned (Fig. 1: A). Traces of the early Slavic settlement were discovered in the south-eastern part of the site, shielded - from the East and South - by slopes of the upland over the confluence of the Rovenský creek and the Teplica river (Fig. 1: B).

\section{FEATURE 32}

The sunken house was rectangular or slightly trapezoid with a flat bottom and sloping sidewalls. The backfill consisted of a compact un-layered black-brown soil consistent with the local topsoil. The fact that the walls were slightly sloping could be attributed to destruction processes after the feature ceased to be used in its primary function. 


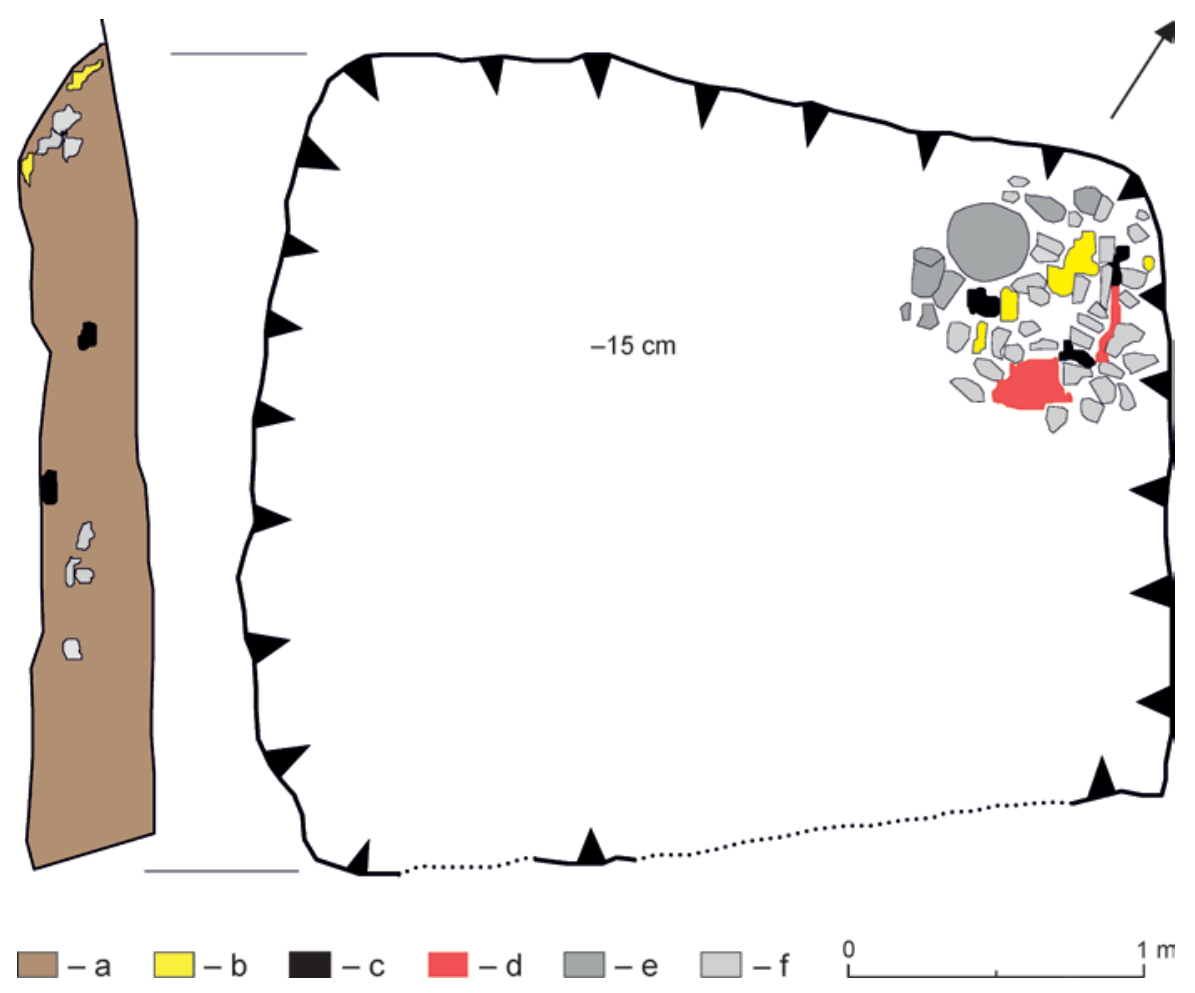

Fig. 2. Senica, part Párovce. Feature 32, a sunken house from the early Slavic period. Legend: a - dark brown clay-like soil; b - loess-clay soil; c - a charcoal fragment or an ash layer; $\mathrm{d}$ - burnt soil; e - stones from the furnace body, on-site; $\mathrm{f}$ - stones from the furnace destruction.

In its north-eastern corner, remains of a heating device - a furnace - were found. The furnace was built from crushed stone (granite and fragments of sandstone), in both primary and secondary positions, burnt clay, daub and remains of burnt wood. Judging by the preserved pieces of wood covered with daub, wood could be part of wattle furnishings of a clay dome shelled with stones. The hearth was placed on the floor level and consisted of yellow loess soil coloured grey. Stones forming foundations of the construction - in the primary position found only in the northern part of the dwelling, by the wall - were sunken in the soil. Special attention was focused on a circular stone slab $(0.28 \mathrm{~cm}$ in diam.) located in line with the perimeter wall (Fig. 2). After removing destructed elements, we cannot exclude that, originally, the furnace was built in the shape of an isosceles trapezoid. Presumably, its foundations were wider along the north-eastern wall. The narrower side of the furnace - along the south-western wall - had an opening oriented to the interior of the dwelling. External dimensions of the furnace walls were about 0.8 and $0.5 \mathrm{~m}$ and were placed at a distance of $0.8 \mathrm{~m}$ from each other. The stone foundation wall was only slightly thicker than $0.1 \mathrm{~m}$.

We were unable to capture any postholes - indicating the presence of some above-ground con- struction - either in the flat bottom of the feature, slightly raised in the centre (about $0.04 \mathrm{~m}$ ) with slightly lifted rectangular, or around it. A darker stain in the north-western corner of the dwelling is a fragment of a younger burrow. The south-eastern wall of the dwelling, except for the corners, was considerably damaged by an earth-moving machine used during preliminary preparations of an access route to the Párovce upland. An unreinforced floor was placed at a depth of $0.3-0.34 \mathrm{~m}$ from the upper layer of the light soil. To this, we need to add a layer of black-brown topsoil and subsoil. In this area, the thickness of those layers could range between 0.6 and $0.8 \mathrm{~m}$. However, we need to take into account that the original terrain was considerably altered by various agricultural activities performed there throughout the centuries, mostly by horticulture and greenhouses. Generally, the feature was $3.1 \mathrm{~m}$ long and 2.1-2.72 $\mathrm{m}$ wide (Fig. 2).

134 pottery shreds were extracted from the backfill of feature 32. Most of them were fragments of early Slavic vessels. Using the shreds, it was possible to reconstruct three vessels.

1. A smaller mug-like pot (a cup). The item was hand-made from a granular material without a potter's wheel. The pot has a flat bottom, a barrel-shaped body and a low, cylindrical mouth. The widest part of the pot is slightly 


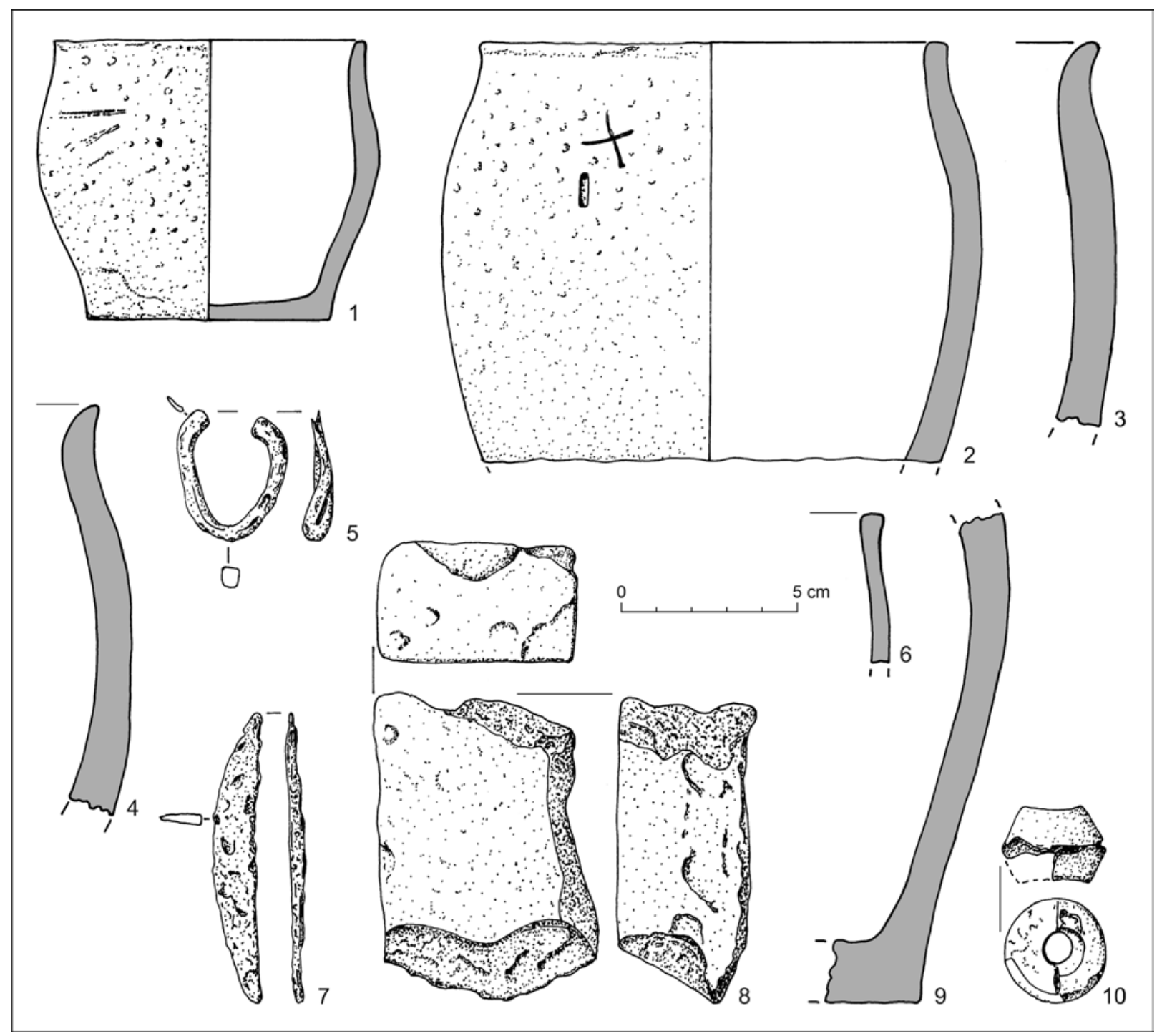

Fig. 3. Senica, part Párovce, feature 32. 1-4, 6, 9 - pottery; 5 - an eyelet made from an iron wire; 7 - an iron knife with a convex blade; 8 - sandstone whetstone; 10 - ceramic spindle whorl.

above half of the item height. The item's light-dark brown surface is undecorated, but rough due to the presence of sand grains. It is clear, however, that a considerable effort was put to smooth the grains out. This effort is evidenced by horizontal and oblique stripes smudges made with fingertips with traces of blurred papillary lines. Inside, the pot is ochre and brown-black. Dimensions: height $7.9 \mathrm{~cm}$, bottom diam. $7 \mathrm{~cm}$, widest diam. $9.8 \mathrm{~cm}$, mouth diam. $8.5 \mathrm{~cm}$ (Fig. 3: 1).

2. A pot-like vessel (about $30 \%$ of the lower part with the bottom is missing). It was hand-made from a granular material without a potter's wheel. The vessel is widest in its upper third and has a low, cylindrical, straight-cut irregular mouth. The item's brown-dark brown surface is undecorated, but rough due to the presence of sand grains. A considerable effort was put to smooth the grains out. This effort is evidenced by horizontal and oblique stripes - smudges made with fingertips with traces of blurred papillary lines. On the back, in still-wet clay, a delicate isosceles cross with bent arms - slightly tilted to the left - was engraved. Below, there is a rectangular cavity - a trace of burnt organic material. Inside, the vessel is ochre. Preserved dimensions: height $12 \mathrm{~cm}$, mouth diam. $13.4 \mathrm{~cm}$, widest diam. $15.8 \mathrm{~cm}$, diam. of the preserved bottom part $13.3 \mathrm{~cm}$, mouth thickness $0.6 \mathrm{~cm}$, bottom thickness $0.9 \mathrm{~cm}$, cross dimensions $1.6 \times 1.5 \mathrm{~cm}$, cross thickness $0.05-0.1 \mathrm{~cm}$ (Fig. 3: 2).

3. A bottom and a fragment of the body of a hand-made vessel. The vessel was made from a granular material with its widest part in the upper third of the body and has a flat bottom. There are sand grains on its brownblack surface and traces of smoothing the surface out. The fracture is black. Dimensions: $12 \times 11.4 \mathrm{~cm}$, wall thickness 1-1.2 cm, bottom thickness $2 \mathrm{~cm}$ (Fig. 3: 9).

4.-5. Edges of pot-like vessels with widest parts in the upper third of the body and slightly outwardly curved mouth. The vessels were hand-made from a sandy material. The vessels' surfaces are red-brown-light-brown 
and slightly rough with smudged papillary lines. The fracture is rusty and black. Dimensions: $11.4 \times 8.4 \mathrm{~cm}$ and $10.3 \times 8.6 \mathrm{~cm}$ (Fig. 3: 3, 4).

6. An edge of a pot-like vessel resembling item no. 1 with a low bold cylindrical and horizontally cut mouth. The vessel was made from clay with a small number of fine stones. Its surface is brown with a black spot. The fracture is brick-red. Dimensions: $4.2 \times 3.3 \mathrm{~cm}$, thickness $0.6 \mathrm{~cm}$ (Fig. 3: 6).

Intrusions of an older cultural layer comprised single shreds dated roughly back to prehistoric times, the Late La Tène period and the High Middle Ages. Apparently, the latter was moved to the older layer through burrows of various animals. Most shreds of early medieval pottery concentrated around the furnace.

Except for the furnace destruction, there were only five small pieces of daub in the backfill. Together with a wider context of the find, this could indicate that the feature decayed naturally. Organic material - mainly in the northern part of the backfill - contained 60 relatively small fragments of animal bones and a snail shell (Capaea vindobonensis).

The so-called small finds included a transversely cracked spindle whorl, an eyelet made from an iron wire, an iron knife(?), and fragments of a whetstone.

1. A ceramic, bi-conical spindle whorl with a sharp body and flat top and bottom. Its surface is brown, smooth and the fracture is brick-red-grey. The find consists of two parts and about a quarter of the item is missing. Dimensions: diam. $2.9 \mathrm{~cm}$, height $2.2 \mathrm{~cm}$, diam. of the top and the bottom 1.6 and $1.9 \mathrm{~cm}$, opening diam. $0.8 \mathrm{~cm}$ (Fig. 3: 10).

2. An open eyelet made from an iron, rectangular wire with hammered tips. A chain-link(?). Dimensions: length $3.9 \mathrm{~cm}$, width $3.2 \mathrm{~cm}$, wire thickness $0.6 \mathrm{~cm}$, weight $10.68 \mathrm{~g}$ (Fig. 3: 5).

3. A pointed iron strap with one convex and one concave side, without a blade. Judging by a broken tang the knife had a convex blade. Dimensions: length $8.2 \mathrm{~cm}$, max. height $1.4 \mathrm{~cm}$, thickness $0.4 \mathrm{~cm}$, weight $9.68 \mathrm{~g}$ (Fig. 3: 7).

4. A whetstone made from a rusty sandstone with a slightly convex upper side and untreated slate base. Its sides are vertically ground. Shorter sides are broken. Dimensions: length $8.5 \mathrm{~cm}$, width $6.8 \mathrm{~cm}$, thickness $4.4 \mathrm{~cm}$, weight $248.14 \mathrm{~g}$ (Fig. 3: 8).

The dating of feature 32 from Senica, Párovce, relies mainly on the pottery, particularly the reconstructed or partially reconstructed vessels. All the vessels were hand-made, without a potter's wheel, from clay containing fine-grained silica sand and in some cases also organic material. Except for a small, isosceles - the so-called Greek - cross engraved on the back of a slim, tall pot-like vessel (Fig. 3: 2), there were no traces of decoration on the shreds.
Simple engraved crosses, whether upright, inclined or resembling a swastika are relatively common decorations of the early Slavic pottery from Romanian Moldova, Muntenia and Oltenia, through Upper Odra and Elbe regions up to Central Bohemia (Parczewski 2001, fig. 1; Teodor/Stanciu 2009, 129). A separate collection of finds comes from the Czech Pomoravia (surroundigs of river Morava; Jelínková 1990, 262, fig. 3: 7; 7: 5; Parczewski 2001, fig. 1) and the find from Senica could be - at least geographically - attributed to it. From Slovakia, possibly a vessel from Galanta, part Matúškovo, could be linked with those finds. The vessel is decorated by five punctures on the belly arranged into a cross motif (Fusek 1994, 61, pl. XIII: 1).

The cross on the vessel from Senica is rather a 'sign' or a symbol than an ornament (Jelinková 1990, 262) without any direct reference to its later Christian meaning. Although, for instance, in Romania, in the $6^{\text {th }}$ and $7^{\text {th }} \mathrm{c}$. such symbolic meaning of the cross motif could not be ruled out. Particularly Wallachia was at that time strongly influenced by the Byzantine culture. However, in Bohemia, Moravia and northwestern Slovakia such application of a cross is rather unlikely (Parczewski 2001, 20; Stanciu 2018, 307-324). The cross motif was known already in prehistoric art and, in addition to decorative function, it had also a deeply symbolic and magic meaning (e.g. Matoušek/ Štajnochr 2001, 177) that lasted during the Christian times (Karbusický 1963, 298) although often had loose relations to the official Christian teaching.

The vessels surface is rough - a consequence of the clay used for its manufacturing. However, there are clear traces - manufacturer's smudged papillary lines - of a considerable effort to smooth the surface out, mainly by hand. Burnt vessels have various shades of brown with black spots here and there. Slim vessels with the low, slightly outwardly curved mouth are consistent with early Slavic pottery (Bialeková 1962, 97 ff.), the Prague-type, group I pottery - Borkovský type - i.e. slim vase-like vessels (PleineroválZeman 1970, 724). At the same time, they are closely related to the $1^{\text {st }}$ settlement phase of Prague-type pottery finds in Moravia (Jelínková 1990, $258 \mathrm{ff}$.) or the I horizon of the early Slavic, undecorated pottery from Bajč (Ruttkay 2002, 269). According to the classification by G. Fusek (1994, $34-38,52,53)$, the partially reconstructed vessel and two larger shreds of upper parts of pots (Fig. 3: 2-4) could be attributed to the group of slim handcrafted, unrounded pots with cylindrical or slightly outwardly curved mouths. The small muglike pot and also a fragment of another, similar item belong to a group of miniature vessels lower than

\footnotetext{
1 We consider the term Prague culture as imprecise from the linguistic, terminological as well as historic as archaeological perspective. Instead, we would prefer a more descriptive term - the culture of tribes with Prague-type pottery.
} 
$8 \mathrm{~cm}$ (Fusek 1994, 77). The scarce ceramic material, thus, allows linking feature 32 from Senica to the I phase of early Slavic settlement in Slovakia (Ruttkay 2002, 250), most likely to the period corresponding to the Ia stage (Fusek 1994, 73, 74, 101), i.e. to the $6^{\text {th }} \mathrm{c}$.

In terms of typology and material, pottery from the Parovce upland resembles also finds from $\mathrm{Su}-$ chohrad - attributed by G. Fusek and J. Zábojník (2010, 163), with utmost probability, to the oldest phase (Ia) of the Prague culture. ${ }^{1}$ Thus, it is possible that the settlement in Senica, part Párovce, had emerged already before the Avars came to the Carpathian Basin and the Lombards went to north Italy (Fusek 1994, 103). The material from Senica, however, does not confirm mutual contacts between those two culturally and linguistically different ethnic groups. If, however, the site in Senica was dated back to the times before $568 \mathrm{CE}$, the lack of documented contacts between the groups could be related, among others, to the relatively large distance between the Chvojnice Upland and lower reaches of the Moravia, close to the place where Moravia flows into the Danube (Kraskovská 1963, 693 ff.; 1968, 209 ff.; Turčan 2012), where settlement dated back to the final phase of the Migration Period is well-documented. Hopefully, the chronology of the site will be refined by further research and radiocarbon dating of organic material.

Other finds - a bi-conical spindle whorl typical for the period (Fusek 1994, 80; Ruttkay 2002, 278), an iron knife with a convex blade, an eyelet and possibly also chain links as well as a whetstone (rather than a touchstone; Ježek 2012, 26-49) made from local sandstone (Fig. 3: 5, 7, 8, 10) provide little chronological information. Together with numerous fragments of animal bones, the finds simply support the view that the settlement was used for a longer time with an economy based on agriculture, domestic animals breeding and local craft production.

Sunken houses - mostly rectangular with a furnace in a corner - were characteristic dwellings in the early Slavic period (Bialeková 1962, 122; Šalkovský $1998,10)$. With time, the dimensions of the sunken houses increased and in phases $\mathrm{Ia}$ and $\mathrm{Ib}$ the inner surface could be as large as $9.05-9.54 \mathrm{~m}^{2}$ (Fusek 1994, 128, 129). In Bajč, the most common were the type I dwellings, a square or rectangular pit without postholes and dimensions ranging from 4.8 to $18.4 \mathrm{~m}^{2}-$ most frequently between 6.5 and $12 \mathrm{~m}^{2}$ (Ruttkay 2002, 251). The sunken house from Senicawith a surface of $7.7 \mathrm{~m}^{2}$ - could be attributed to this category. It is believed that underground parts of the dwellings were mostly wooden (Ruttkay 2002, 256) made from beams using the log or quasi-log technique (Šalkovský 1998, 16).
The only exceptional characteristic of the feature is the trapezoidal furnace - or rather its remains with a flat round stone hearth at the firebox opening that could have been used as a 'hot plate'.

\section{CONCLUSIONS}

The rescue archaeological research in Senica, in the Párovce upland, revealed a fragment of an early Slavic settlement dated back to the $6^{\text {th }}$ c., probably before $568 \mathrm{CE}$. So far, during the excavations, we have discovered a sunken house with a furnace (feature 32; Fig. 2) and a nearby unspecified, pit-like settlement feature (feature; Fig. 4).

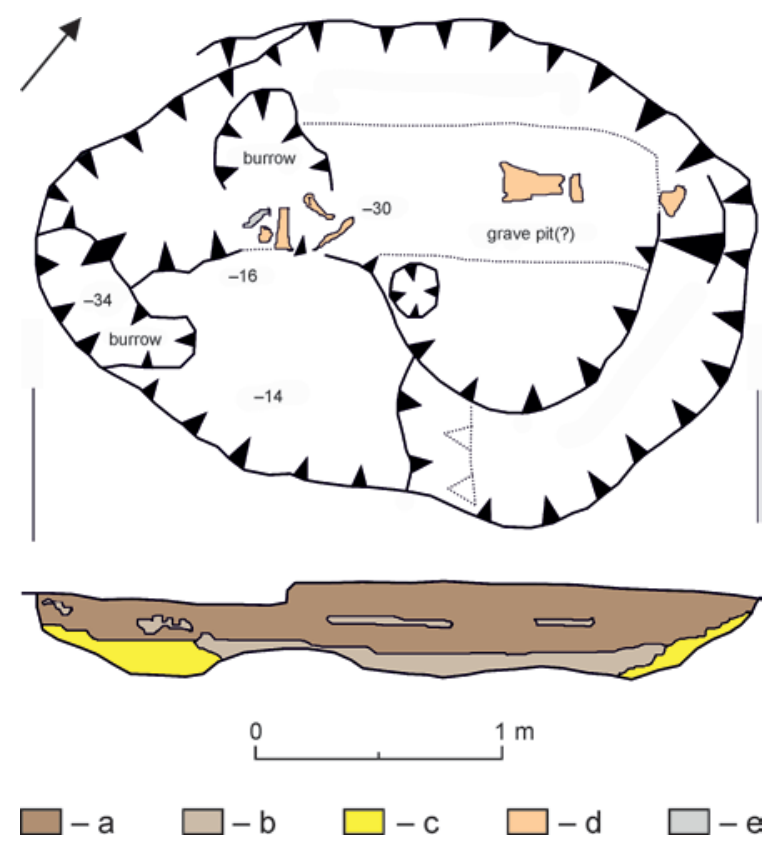

Fig. 4. Senica, part Párovce. Feature 39, a settlement pit from the early Slavic period. Legend: a - dark brown claylike soil; b - light brown clay-like soil; c - yellow loess; $\mathrm{d}$ - bones; $\mathrm{e}-\mathrm{a}$ stone.

According to the older literature, early Slavic settlement in Záhorie concentrated mainly in the vicinity of the Moravia (Bialeková 1962, fig. 52; Fusek 1994, Map 1; Fusek/Zábojník 2010, 155 ff.). However, more recent findings confirmed settlements related to the phase Ia of the Prague culture in Záhorie in Suchohrad (Fusek/Zábojník 2010, 155 ff.) and on sandy clays of Búry in Lakšárska Nová Ves (Tomčíková 1991, 69 ff.). The newest research points to another site in Senice in the Chvojnická upland in the Myjava and Teplica (its right-bank tributary) valleys. 


\section{BIBLIOGRAPHY}

Bialeková 1962 -D. Bialeková: Nové včasnoslovanské nálezy z juhozápadného Slovenska. Slovenská archeológia 10, 1962, 97-148.

Daňo 2011 - R. Daňo: Archeologický výskum na stavbe OC KAUFLAND v Senici. AVANS 2008, 2011, 81.

Fusek 1994-G. Fusek: Slovensko vo včasnoslovanskom období. Archaeologica Slovaca Monographiae. Studia 3. Nitra 1994.

Fusek/Zábojník 2010 - J. Fusek/J. Zábojník: Frühslawisches Siedlungsobjekt aus Suchohrad. In: J. Beljak/G. Březinová/V. Varsik (eds.): Archeológia Barbarov 2009. Hospodárstvo Germánov. Archaeologica Slovaca Monographiae. Communicationes 10. Nitra 2010, 155-180.

Hoššo/Piatničková/Šuteková 2011 - J. Hoššo/K. Piatničková/ J. Šuteková: Záchranný výskum na stavbe Obchodná zóna v Senici. AVANS 2008, 2011, 108, 109.

Jelínková 1990 - D. Jelínková: K chronologii sídlištních nálezů s keramikou pražského typu na Moravě. In: Pravěké a slovanské osídlení Moravy. Sborník k 80. narozeninám Josefa Poulíka. Brno 1990, 251-281.

Ježek 2012 - M. Ježek: Prubiřský kámen raně středověké společnosti. Archeologické rozhledy 64, 2012, 26-58.

Karbusický 1963 - V. Karbusický: Žánrová podstata a datování lucké války v Kosmově kronice. Český lid 50, 1963, 292-304.

Kraskovská 1963 - L'. Kraskovská: Nálezy z doby stahovania národov na západnom Slovensku. Archeologické rozhledy 15, 1963, 693-700.

Kraskovská 1968 - L’. Kraskovská: Hroby z doby st’ahovania národov pri Devínskom Jazere. Archeologické rozhledy 20, 1968, 209-212.

Matoušek/Štajnochr 2001 - V. Matoušek/V. Štajnochr: Pozdně eneolitická pohřební keramika v Čechách. Archeologie ve středních Čechách 5, 2001, 153-200.

Manuscript accepted 3. 7. 2021

Translated by Magdalena Adamus

PhDr. Zdeněk Farkaš, PhD.

SNM - Archeologické múzeum

Žižkova 12

P. O. Box 13

SK - 81006 Bratislava

zdenek.farkas@snm.sk
Parczewski 2001 -M. Parczewski: Ornament czy symbol kultu? Znak krzyża na naczyniach wczesnosłowiańskich. In: J. Gancarski (red.): Dzieje Podkarpacia. Tom V. Poczatki chrześcijaństwa w Małopolsce. Krosno 2001, 15-21.

Pleinerová/Zeman 1970 - I. Pleinerová/J. Zeman: Návrh klasifikace časně slovanské keramiky v Čechách. Archeologické rozhledy 22, 1970, 721-732.

Ruttkay 2002 - M. Ruttkay: Mittelalterliche Siedlung und Gräberfeld in Bajč-Medzi kanálmi (Vorbericht). Slovenská archeológia 50, 2002, 245-322.

Šalkovský 1998 - P. Šalkovský: Dedinský dom a sídlo vo včasnom stredoveku. In: L'udová architektúra a urbanizmus vidieckych sídiel na Slovensku. Bratislava 1998, 9-36.

Stanciu 2018 - I. Stanciu: Cross-shaped signs on $6^{\text {th }}$ and $7^{\text {th }}$ centuries pottery. In: D. Aparaschivei/G. Bilavschi (eds.): Studia Romana ed mediaevalia Europaensia. Miscellanea in honorem annos LXXXV peragentis Professoris emeritiu Dan Gh. Teodor oblata. Honoria 13. Bucureşti Brăila 2018, 307-354.

Teodor/Stanciu 2009 - E. S. Teodor/I. Stanciu: About Crosses on Wet Clay as a Cultural Marker. Ephemeris Napocensis 19, 2009, 129-155.

Tomčíková 1991 - K. Tomčíková: Včasnoslovanské sídliskové nálezy v Lakšárskej Novej Vsi. Zborník SNM 85. Archeológia 1, 1991, 69-84.

Turčan 2012 - V. Turčan: Stahovanie národov v naddunajskej časti Bratislavy. In: J. Šedivý/T. Štefanovičová (zost.): Dejiny Bratislavy 1. Od počiatkov do prelomu 12. a 13. storočia. Brezalauspurc na križovatke dejín. Bratislava 2012, 285, 286.

Vávra/Bača 2016 - R. Vávra/M. Bača: Osídlenie z neskorej doby bronzovej v Senici, poloha Sedlička. Musaica Archaeologica 2, 2016, 55-126.

Mgr. Pavol Jelínek, PhD.

SNM - Archeologické múzeum

Žižkova 12

P. O. Box 13

SK - 81006 Bratislava

pavol.jelinek@gmail.com

Mgr. Igor Choma

SNM - Archeologické múzeum

Žižkova 12

P. O. Box 13

SK - 81006 Bratislava

igor.choma@gmail.com 